

TRANSFORMATION, INTEGRATION and GLOBALIZATION ICONOMIC RESEARCH CENTRUM BADAWCZE TRANSFORMACJI, INTEGRACJI I GLOBALIZACJI

TiGER Working Paper Series

No. 112

\title{
Structural Change without Trust: Reform Cycles in Hungary and Slovakia
}

\section{Dóra Győrffy}

Warsaw, June 2008 


\title{
Structural Change without Trust:
}

\section{Reform Cycles in Hungary and Slovakia ${ }^{1}$}

\author{
By \\ Dóra Győrffy \\ Assistant Professor \\ University of Debrecen, Faculty of Economics \\ 4028. Debrecen Kassai út 28. Hungary \\ E-mail: dora.gyorffy@econ.unideb.hu
}

\begin{abstract}
The recent admission of Slovakia into the Economic and Monetary Union (EMU) stands in sharp contrast with the considerable difficulties faced by Hungary with the fulfillment of the Maastricht criteria. This is a puzzling development for two reasons: first, during the early phase of the transition process Hungary was way ahead of Slovakia, and second, the high level of political polarization and general public disillusionment is a shared characteristic of the two countries and not conducive to reforms in either case. In order to address these puzzles a theoretical framework is developed examining the conditions of structural reforms in a low-trust environment, where promises about long-term benefits for short-term costs are not believed. After the identification of potential factors that can overcome the gap in credibility, the theoretical framework is applied to the transition history of the two countries. Based on this comparative analysis it is shown that in a both cases reform cycles rather than sustainable progress can be observed. The main conclusion of the analysis is that their current differences can be explained partly by their different position in the reform cycle and partly by the longer rule of reformers in Slovakia. This implies that in the absence of an elite consensus on continuing the reforms, the current success of Slovakia might prove temporary similarly to that of Hungary in the 1990s. The loss of an external disciplining force after Slovakia's recent admission into the EMU increases the chances of such development.
\end{abstract}

JEL Classification: E60, O11, P16, P52

Keywords: trust, political economy of reforms, Hungary, Slovakia, EMU enlargement

\footnotetext{
${ }^{1}$ This research was supported by the Bólyai Fellowship of the Hungarian Academy of Sciences. An earlier version of this article was presented at the Economic Policy Roundtable conference at the University of Debrecen 28 March, 2008. For helpful comments I am grateful to László Csaba and Lajos Bokros.
} 
Sic Transit Gloria Mundi ${ }^{2}$. Hungary's economic performance in the past decade reminds us to the truth in the ancient maxim. Since the new millennium the former leader of transformation gradually fell behind and has become a laggard among the Central and Eastern European countries. In 2008 Hungary is the only new European Union member state, which does not fulfill any of the Maastricht criteria, while it records the lowest growth rate in the region. The experiences of neighboring Slovakia present a sharp contrast to this performance as the country has come out from international isolation and is now hailed as a top reformer among emerging economies. Its recent achievements are validated by gaining admission into the Economic and Monetary Union (EMU). When reflecting on the twists and turns of transition, two questions can be posed, which have considerable significance beyond these two cases. 1 . What are the factors, which are responsible for the change in the two country's relative position? 2. How lasting are these changes?

Previous research on the comparative politics of structural reforms has called attention to two important factors, which might account for the divergent experiences of these two countries. O'Dwyer and Kovalcik (2007) argue that in contrast to Hungary the under-institutionalization of the Slovakian party system resulted in the insulation of reformers and thus allowed them to enact radical change ${ }^{3}$. Greskovits (2008) underlines the dissimilar importance attached to material benefits and identity in the two cases, which affected their compliance with the Maastricht criteria. While both arguments reveal important factors regarding the differences between the two countries, they share the problem of external validity, which means that they cannot account for reforms or the lack of them when applied to cases outside the sample. The thesis of O'Dwyer and Kovalcik fails when we consider the successful reforms that took place in a number of advanced European states such as Sweden, Finland or Ireland, which all had stable party systems. The argument put forward by Greskovits is very specific to the two countries and thus its applicability to other countries is strongly limited.

This paper approaches the proposed questions from a broader theoretical perspective, which allows the development of more generalizable explanations as well as facilitates predictions on the future development of the two countries. Structural reforms are conceptualized as an implicit commitment from the government that in exchange for short-term sacrifices and increasing uncertainty long-term benefits will follow. If this commitment is not credible due to lack of trust in the system in general and policy-makers in particular, structural reforms arouse substantial resistance and will be improbable unless exceptional conditions prevail. However once these conditions are gone, reforms are likely to slow down or reverse as politicians aim to buy support through short-term interventions. Since these measures can easily lead the economy into a crisis, the window of opportunity for reforms can open again. This means that in a low-trust environment reforms are likely to remain cyclical. In order to ensure their sustainability the difficult tasks of consensus- and trust-building cannot be avoided. The main implication of this thesis is that the continued success of Slovakia cannot be taken for granted while the necessary resumption of structural reforms would be only a first step towards convergence in Hungary.

The paper proceeds as following. The second section develops a theoretical framework for explaining the nature of structural reforms and the difficulties associated with their implementation. This framework is then applied to the cases of Hungary and Slovakia in the

\footnotetext{
${ }^{2}$ Thus passes the glory of the world.

${ }^{3}$ Besides Hungary and Slovakia the authors also test this hypothesis on the cases of Estonia, the Czech Republic and Romania.
} 
following two sections. The fourth section compares the two cases and identifies reform cycles in both countries. The final section concludes.

\section{Structural reforms and trust}

In order to derive hypotheses about the conditions under which structural reforms are likely to take place, first it is necessary to consider the main characteristics of such reforms. Antal (2007) defines structural reforms as the following (59):

1. Reforms change the fundamental incentive structure of economic actors, and thus lead to a deep and lasting transformation of the allocation mechanisms in the economy while leaving the power structure intact.

2. The changes are directed towards increasing the role of market forces as well as individuals' autonomy of choice vis-à-vis hierarchical bargaining and the bureaucratic power of the state.

While reforms are generally associated with deregulation it is important to note that their main aim is to facilitate market coordination, which might require more, rather than less regulation, such as a strong competition policy (IMF 2004: 125).

Although greater reliance on market forces for the allocation of resources is generally beneficial, reforms are far from being without costs and thus policy-makers face a series of constraints when implementing them ${ }^{4}$. These constraints can be classified into three groups. First, while society as a whole may be a winner of reforms, some people may suffer from losing protection from market forces. As a small group of losers can better organize than a dispersed group of winners (Olson 1965), there might be considerable resistance even to highly advantageous changes. Second, while there may be benefits even for those who are among the losers, these benefits might only materialize in the long-term and thus a tradeoff emerges between the short- and the long-term. Given the psychological preference for the former (Elster 2000: 25), resistance might occur even from future winners of the reforms. Third, uncertainty over the outcomes of reforms can also present obstacles to change as people do not know whether they will be among the losers and whether it will be in the shortterm or the long-term.

When designing structural reforms governments have to address the above constraints. Assuming that they introduce reforms only if society as a whole benefits from them, they need to implement parallel measures to reduce the constraints to reforms. Those in the first group, who are permanent losers of the reform, have to be compensated both because of utilitarian and moral considerations. The utilitarian logic requires compensation in order to reduce the resistance to reforms, while the moral argument is that society has an obligation to redistribute some of its gains to those who suffer for those benefits. For people in the second group the government has to design policies, which facilitate their adaptation to the new environment. Finally, providing reliable information can reduce the uncertainty and thus the resistance of those who fall into the third group.

Reducing resistance to reforms however is far from being a simply technical exercise. When promising long-term benefits for the majority and compensation for the minority, the government is making an explicit commitment to some future development. Whether this

\footnotetext{
${ }^{4}$ This paragraph heavily relies on IMF (2004): 109-110.
} 
commitment is seen as credible ${ }^{5}$ crucially affects the success of reforms. If people do not believe the promises of the government, the proposed solutions for reducing public resistance to reforms are bound to fail. The first group will not believe that compensation will be forthcoming or cover their losses sufficiently. For the second group while the losses will be immediate, long-term gains will not be credible. For the third group the information provided by the government will not be believed and thus will be inadequate to decrease the problem of uncertainty. These problems are summarized in Table 1.

Table 1. Structural reforms: sources of resistance, solutions and the role of credibility

\begin{tabular}{|c|c|c|}
\hline Source of resistance & Solution & Role of credibility \\
\hline $\begin{array}{c}\text { Permanent losers from } \\
\text { market forces }\end{array}$ & $\begin{array}{c}\text { Compensation from societal } \\
\text { gains }\end{array}$ & $\begin{array}{c}\text { Uncertainty over whether } \\
\text { promised compensation will } \\
\text { be forthcoming }\end{array}$ \\
\hline $\begin{array}{c}\text { Short-term losses but long- } \\
\text { term gains with short-term } \\
\text { preferences }\end{array}$ & $\begin{array}{c}\text { Policies facilitating } \\
\text { adaptation to the new } \\
\text { environment }\end{array}$ & $\begin{array}{c}\text { Uncertainty over long-term } \\
\text { gains }\end{array}$ \\
\hline $\begin{array}{c}\text { Uncertainty over reform } \\
\text { outcomes }\end{array}$ & Provision of information & Unreliability of information \\
\hline
\end{tabular}

Author's own construction

Given the importance of credibility for structural reforms the question how to build it cannot be left unaddressed. For monetary policy two solutions have been offered: reputation-building (Barro and Gordon 1983) and delegation to an independent institution (Rogoff 1985). These solutions are hardly applicable to structural reforms. Reputation-building relies on the idea of repeated games, which means numerous rounds of the game are necessary to achieve the objective. Structural reforms however are better conceptualized as one-round games implying that actors have just one chance to decide whether to consider a commitment credible or not. This feature makes delegation a similarly unrealistic proposal. However once we consider the history of the game involving the past behavior of policy-makers as ingrained in collective memory, we can assume that the credibility of individual politicians will be strongly affected by it. The importance of state apparatus for the implementation of reforms provides a rational justification for using such short-cut.

Recognizing the importance of collective memories for assessing individual politicians' credibility leads us to the relevance of political trust, which can be viewed as the accumulation of experiences with the system ${ }^{6}$. While the concept of political trust has been widely debated in the social sciences ${ }^{7}$, in this paper I follow the definition of Anderson et al (2005) who define trust as "the belief, that the political system will produce 'good' outcomes" (19). Without the presence of such belief it becomes very difficult for a politician to make credible promises regarding the future and thus it becomes very difficult to reduce the resistance to reforms.

\footnotetext{
${ }^{5}$ The concept of credibility was formulated by Kydland and Prescott (1977) for monetary policy. It refers to the problem of time inconsistency, which means that a decision, which is optimal at time $t$, will not be optimal at time $\mathrm{t}+\mathrm{s}$ under new conditions. As the public is aware of this incentive structure, the government loses its ability to influence people's decisions that results in suboptimal outcomes such as higher inflation.

${ }^{6}$ For a systemic modeling of trust in government as a continous learning process see Martinez-Moyano et al (2007). For an extensive discussion on the relationship between collective memories and trust see Rothstein (2005) 148-166.

${ }^{7}$ For an extensive review see Blind (2007)
} 
The difficulty of credible commitment in a low-trust environment however does not mean that reforms are always impossible. There are four different situations in which the obstacle of lack of credibility can be overcome.

1. If a politician can sufficiently differentiate him- or herself from the rest of the political elite, such as through coming from outside of the former power structure, it might be possible to convince the electorate about the start of a new era and the possibility of carry out the reforms in spite of the obstacles in the state apparatus.

2. If the situation deteriorates to the extent that citizens believe that any policy is better than the present one, then a crisis can ease the resistance to reforms ${ }^{8}$.

3. If the elite come to a consensus over the necessity of change and no alternative to the reform path is presented, there is no mechanism to channel the resistance and thus it cannot present a serious obstacle to reform.

4. In an authoritarian regime without free elections resistance can be dealt through force rather than persuasion.

Once we accept the importance of credibility and trust in implementing reforms we can hypothesize that unless one or more of these four factors are present, structural reforms are improbable since the cost of resistance for politicians are likely to be considerably higher than the gains from the reforms that might materialize only for the following government.

Lack of trust however not only makes structural reforms unlikely but can also contribute to deterioration in economic performance. If politicians' promises cannot be trusted, the only way to buy support is through short-term material benefits (Easton 1965: 273). These might take various forms including increased social spending, lowering taxes, subsidized credit or protection of certain sensitive sectors from competitive pressures. Such short-term measures however have easily foreseeable negative effects in the medium-term, which in turn decreases the level of trust further and results in a vicious cycle of lack of trust and bad performance.

The vicious cycle increases the possibility of one of the three states (with the exception of authoritarianism) to prevail under which reforms become possible even in a low-trust environment. However, even if reforms are implemented due to such factors, they are unlikely to be sustained unless trust is established through improving performance. Once the crisis passes and difficult decisions have been made, politicians might feel the need to ease their policy and compensate the population for the hardships. While a new leader might have had credibility before the reforms he or she might lose it easily as the hardships prevail and thus face considerable resistance to continuing them. Finally, elite consensus can easily break down as it becomes more and more beneficial to the participants to oppose the unpopular changes. Based on these considerations it can be hypothesized that if reforms are implemented but do not contribute to increased systemic trust, the passing of special conditions might easily lead the economy back to the vicious cycle of short-term interventions, bad performance and low trust. As this might lead again to a crisis situation, over the long-term we can expect reform cycles rather than sustainable development in lowtrust regimes.

The following sections will first describe the reforms since the transition in Hungary and in Slovakia and then discuss how this theory can be applied to these cases.

\footnotetext{
${ }^{8}$ For a formal statement of the benefit of crisis for reforms see Drazen and Grilli (1992).
} 


\section{Reform cycles in Hungary and Slovakia}

Hungary and Slovakia seems like a natural comparison when we examine economic reforms. They are neighboring countries and share a considerable part of their history. They are also small open economies, members of the European Union, and both are aiming at introducing the euro as soon as possible - although with different degree of success. The main dissimilarity between them is that Slovakia became an independent state only in 1992. This difference however should not be the whole explanation for the more successful reforms in Slovakia, since as the contradictory experiences of the Baltic States and the Western Balkans show, new-found statehood can be a reason both for implementing and for postponing reforms. The history of economic reforms in Slovakia also reflects this duality, which in itself needs explanation.

In the theoretical part the role of political trust has been emphasized as a critical determinant in shaping the unfolding of reforms. In this aspect the two countries are also highly similar and both suffer from a considerable lack of trust. While a thorough overview about the roots of this distrust would require a separate analysis, four major reasons can be mentioned for the persistent lack of trust in the two countries ${ }^{9}$.

1. Material losses, due to the transformational recession, are a shared experience of the two countries. The loss of output between 1989 and 1993 amounted to 18 percent in Hungary and 25 percent in Slovakia (UN ECE 2003: 112). The consequences were decreasing consumption and rising unemployment. Real total consumption expenditure reached its pre-transition levels only in 2000 in Hungary and 2002 in Slovakia (UN ECE 2003: 113). In Hungary by 1996 employment decreased to 69.8 percent of the 1989-level, while Slovakia did slightly better on this indicator reaching the bottom at 84 percent in 1994 . However, better employment performance came with an extremely high unemployment rate: by 1999 unemployment reached 19.2 percent, while it fluctuated around 10 percent in Hungary (UN ECE 2003: 115 and 117). Rising inequality accompanied these processes: over the transition the Giniindex rose by 19 percent in Hungary and 38 percent in Slovakia (Kornai 2006: 229).

2. Subjective feelings of injustice aggravated the objective losses. The old elite were generally perceived to have fared much better during the transition than the population at large. Incumbents dominated or were perceived to dominate privatization, which led to the cementing of their position in the new regime. In Slovakia the dominance of the old manager-class during the privatization is a historical fact (Appel and Gould 2000), while in Hungary it is only partially true but still remains a widespread perception (Laki and Szalai 2006).

3. Unrealistic expectations of the new system can similarly contribute to the general disillusionment. Transformation was originally perceived as a way to close the gap in living standards with the advanced West. As this did not materialize, disappointment was coded into the system. In spite of the considerable increase in living standards as measured by the availability of various consumer goods (EBRD 2007: 6), nostalgia for the previous regime has remained widespread. The strong attachment to the old regime both in Slovakia and Hungary can be seen from Figure 1.

4. Failures of the new system are also a source of justified disillusionment. Endemic corruption, policy and institutional failures contribute to a sense of skepticism regarding the new system. Over 70 percent in Hungary and 60 percent in Slovakia

\footnotetext{
${ }^{9}$ In this section I rely substantially on Kornai (2006): 227-237.
} 
believe that there is more corruption in the new system than in the old regime (EBRD 2007: 51 and 75).

Figure 1. Views on the old regime*

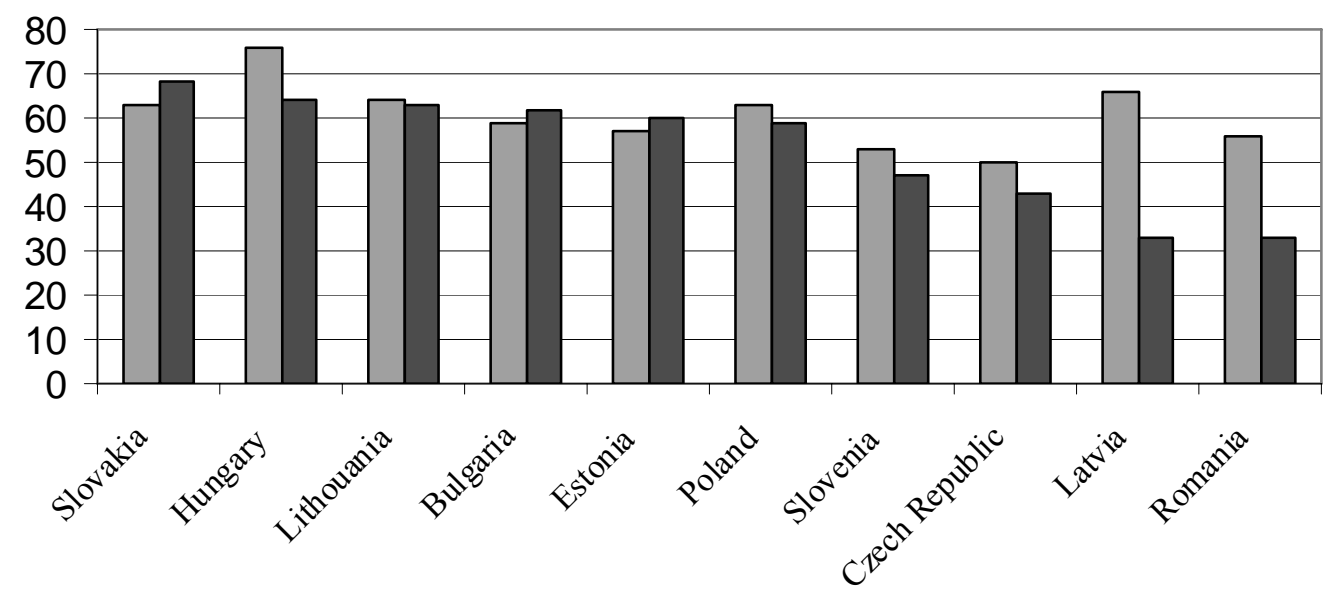

$\square 1993 \square 2004$

* \% of population agreeing with the statement that life was better under communism.

Data: Rose (2006): 39

Figure 2. Trust in public institutions in Hungary (2006)

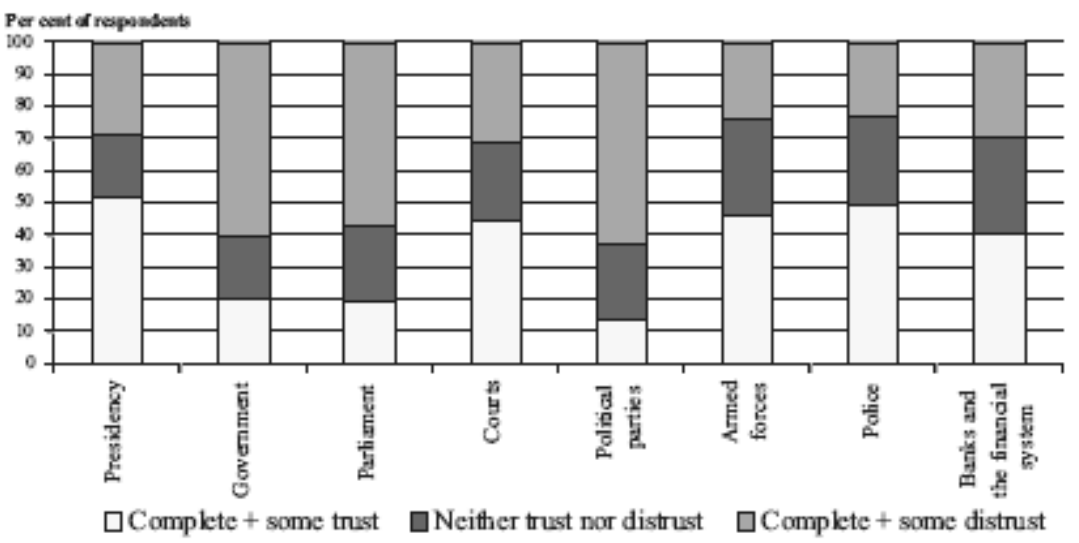

Source: EBRD (2007): 51

Figure 3. Trust in public institutions in Slovakia (2006)

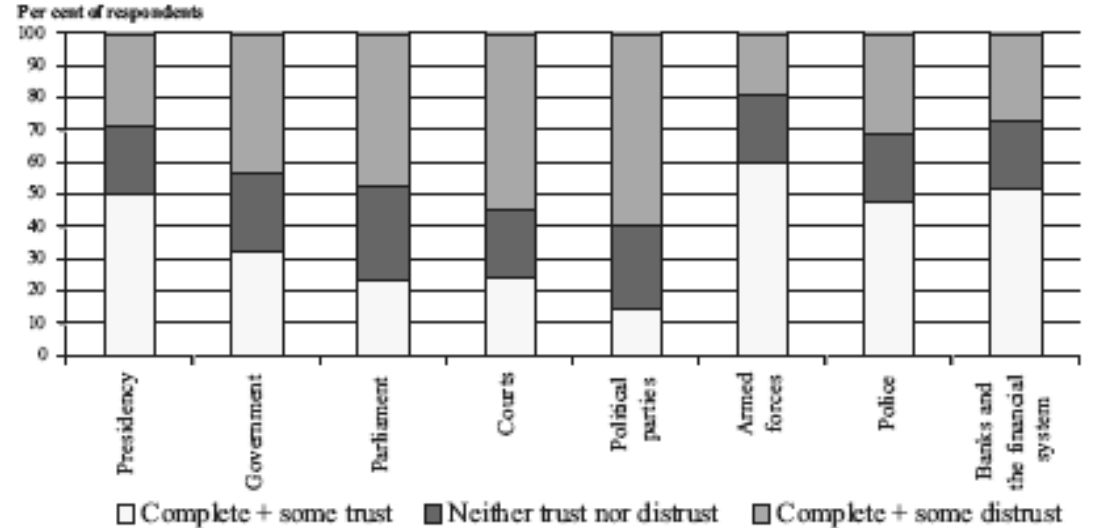

Source: EBRD (2007): 75 
Figure 2 and 3 show a strong general distrust towards the new regime and especially towards the representative institutions such as the parliament and the political parties. The next two sections examine how the theoretical considerations about the difficulties of reforms in lowtrust environment prevailed in Hungary and Slovakia.

\section{The emergence of a vicious cycle in Hungary}

\section{Elite consensus and transition}

Hungary started market reforms with considerable advantages over other transformation countries. First, market reforms had already started as early as 1968, and in spite of periodic reversals they were continued up until the transition. As a result of the reforms undertaken by the last Socialist government ${ }^{10}$ by the time of regime change 90 percent of the prices had been already liberalized and thus there was no need for stabilization (Bokros 1993). Second, there was a widespread consensus among the major political actors over the main tasks of transformation - the establishment of democracy and market economy that would eventually lead the country into the European Union (Balázs 1996; Bozóki 2003: 124-130).

The political consensus was mirrored in the economics profession about the idea that for a small-open economy, export-led growth is the way to sustainable development (Csaba 1998a: 127-135, Mihályi 2005: 85-87). At the time of transition there was no clear political divide among Hungarian economists, which meant that similar advice was given to the main parties (Csaba 1998a: 137). While it did not mean that economists agreed in every important question or that they orchestrated the transition, the professional consensus proved to be very important in two major areas: privatization to foreign investors and the hardening of the budget constraint.

Creating real owners in the economy was seen as a precondition for a functioning market economy. Privatization in Hungary started already in the 1980s when spontaneous privatization by the management was encouraged ${ }^{11}$. After the regime change in the second round of privatization the major objective was to generate revenue for the state and additional capital for the enterprises, which practically meant the sale of enterprises to foreign investors. This stands in sharp contrast with the experiences of most other transition countries where various public distribution schemes have been tried before selling to foreigners. In Hungary the obligation of inherited debt, which was 73 percent of the GDP in 1989 (László 2001: 846), made foreign sale politically feasible and thus paradoxically helped the country to step on the path of export-led growth (Mihályi 2001).

Besides the creation of real owners, in the country of János Kornai the hardening of budget constraint was also seen as essential for the functioning of a market economy ${ }^{12}$. The measures

\footnotetext{
${ }^{10}$ The last Socialist government from 1988 pursued a radical liberalization policy: 1. it abolished import restrictions without compensation for domestic producers; 2. liberalized all prices except energy as well as abolished exchange rate controls; 3 . encouraged privatization with a preference for sale to the highest bidder (Csaba 1998b: 1381).

${ }^{11}$ While this process was later subject to considerable debate detailed analysis show that this first period of privatization involved about 50-100 companies and HUF 50-170 billion worth of assets, which was a small part of the total value of HUF 2000 billion assets of the 1800 state enterprises (Voszka 1998: 21).

${ }^{12}$ While it is always very difficult to support empirically individual influence on any decision, there is some evidence in this case as Kornai was a member of the advisory team of Mihály Kupa, the minister of finance who
} 
to reach this objective amounted to a microeconomic shock therapy for the economy (Csaba 1998: 1382). In 1992 January four major laws were introduced, which aimed at hardening the budget constraint for all actors in the economy and end the situation of circular indebtedness in the economy. The law on the central bank prohibited the monetary financing of the budget deficit. The law on financial institutions introduced the prudential, safety, transparency and disclosure requirements of the Basle Convention. The law on accounting required companies to comply with international accounting standards. Finally, the bankruptcy law introduced an automatic trigger, which obliged debtors under criminal law to initiate bankruptcy procedures if they were in default for than 90 days ${ }^{13}$.

The foreign-dominated privatization and the hardening of the budget constraint in the economy were very successful in bringing about the fast adjustment of domestic production. Hungary was the major beneficiary from foreign direct investment among the transition countries until 1995 (UN ECE 2003: 127). It was second only to Poland in recovering its industrial output to reach its pre-transition level by 1998 (UN ECE 2003: 114) ${ }^{14}$. At the same time the radical measures also had their costs. During the early-1990s over 30000 companies went through some form of bankruptcy procedures (Ábel-Szakadát 1997: 640), which had farreaching consequences. As discussed in the previous section, during this period employment dropped by 30 percent, unemployment rose to over 12 percent and the loss in GDP was close to 20 percent. The wave of bankruptcies affected the banking sector as well, and the share of non-performing loans reached 32 percent of total company loans by 1993 (Ábel-Szakadát 1997: 643).

\section{Disillusionment, crisis and the breakdown of consensus}

The transformational recession resulted in a fast disillusionment from the transition and soon led to the collapse of the elite consensus. Popular discontent was first manifested in the taxi drivers' blockade in 1990 in response to the government's attempt to raise energy prices. The support by the main opposition parties was the first sign of eroding consensus among the elite (Lengyel 1998: 94-96).

The loss of employment opportunities and rising popular dissatisfaction placed increasing demands on the welfare system of the country. In response to these pressures the government considerably eased the regulations regarding disability pensions, early retirement and maternity benefits ${ }^{15}$ thus sowing the seeds for the current problems of the economy. The pressure to consolidate the banking system ${ }^{16}$, further contributed to the erosion of the earlier commitment for lowering state redistribution. By 1994 consolidated expenditures reached 60.8 percent of the GDP up from 55.8 percent in 1991 (László 2001: 846). The upcoming elections were not favorable for fiscal restraint either and gave a further reason for the government to postpone fiscal consolidation. The massive overspending however did not save the government: the Hungarian Democratic Forum still suffered a devastating defeat at the elections and its mandates dropped from 164 to 38 out of the 386 seats in the Parliament. The

\footnotetext{
initiated the major rules for hardening the budget constraint. In his autobiography Kornai also suggests that he feels he had an influence on Kupa's policies. (Kornai 2005: 378, 382-383).

${ }_{13}^{13}$ Because of the toughness of the law it was called the 'hara-kiri' law (Várhegyi 2002: 34).

${ }^{14}$ No other transition country could achieve this before 2000.

${ }^{15}$ For an overview about the systemic logic of this process see Szalai (2007): 104-129.

${ }^{16}$ The cost of bank consolidation reached over 9.4 percent of the GDP in 1993 and 1994. See Ábel (2001): 163165.
} 
elections were won by the Hungarian Socialist Party, whose mandates went from 33 to 209 seats.

While the growing fiscal deficit (see Figure 4) and the accompanying current account deficit due to foreign financing required immediate actions, the government postponed harsh measures in order to prepare for the municipal elections that were held in October that year. Besides the elections the government also believed that it would be possible to introduce the harsh measures through social consensus and the minister of finance, László Békesi, spent these months negotiating such a consensus ${ }^{17}$. His failure to bring it about was a manifestation that the period of consensual decision-making in Hungarian politics was over.

The problems were addressed only in March 1995 after financial crisis hit Mexico and it was feared that Hungary would be the next to fall ${ }^{18}$. The surprise package implemented by the new minister of finance, Lajos Bokros, relied on monetary, fiscal and incomes policy to stabilize the economy. The main elements were surprise devaluation and the introduction of a crawling peg exchange rate, the levying of an 8 percent import surcharge and a nominal wage freeze in the public sector. Structural reforms played only a marginal role and instead there was an across-the-board type cut reducing primary expenditures from 51.9 to 41.6 percent of GDP (Benczes 2008: 155-157). After the package, the process of privatization, which was stopped before the elections, was resumed in order to generate revenue to cover the debt burden. Similarly to the earlier years, the privileging of foreign strategic investors for the sale of banks and other large enterprises was an explicit governmental policy.

The package achieved its main objective and Hungary avoided a financial crisis without entering into a recession or suffering further employment losses. The devaluation of the exchange rate and the nominal wage freeze greatly improved the competitiveness of the economy and kept the country on an export-led growth-path - the value of merchandise exports doubled between 1995 and 1999 (UN ECE 2003: 121). As a result by 1997 growth resumed and Hungary maintained its reputation as one of the leaders of the transition.

The above results however came at a serious social and political cost. Inflation jumped to 28 percent eroding real wages, which fall by a total of 18 percent in 1995 and 1996. The reduction of entitlements, such as introducing needs-based family allowances or tuition fee in higher education, aimed to signal the importance of individual responsibility in the new regime but their main result was the triggering of a serious resistance to the package. The opposition denied that such harsh measures were necessary and Bokros soon became the least popular figure in the country. After the crisis was over he was forced to resign from his post in 1996. While the pension reform was introduced by his successor in 1997, no major reforms took place for a decade after his leave.

Overall the shock administered by the Bokros package had long-lasting influence on Hungarian economic policy-making. First, the country avoided a financial crisis and thus Hungarian policy-makers never learnt the dangers of irresponsibility in the age of capital mobility. Instead, the unpopularity of the package and the loss of the following elections in 1998 made them extremely reluctant to introduce fiscal restrictions. Promising material benefits to buy support became the norm for all parties before the subsequent elections. Second, as the opposition took advantage of the difficult situation of the government and exploited the resistance to the measures, the consensual policy-making characterizing the

\footnotetext{
${ }^{17}$ For an extensive discussion of these efforts see Lengyel (1998): 291-306.

${ }^{18}$ The following section relies heavily on Győrffy (2008): 90-92.
} 
early phase of transition turned into open hostility among the major forces. These developments eventually eroded the results of the package even though until 2000 the new center-right government successfully maintained fiscal discipline (Benczes 2008: 163-167).

\section{The emergence of vicious cycles in Hungarian economic policy}

Since the turn of the millennium budgetary cycles accompanying elections became the dominant feature of the Hungarian economy. While as it can be seen from Figure 4 peaks in deficit could be observed during elections in the 1990s as well, vote-buying was not the primary concern in the period between elections, which is shown by the measures described in the previous section as well as by the early success of transformation. The period after 2000 can be characterized by the permanent election campaign and the lack of any major reform even in the mid-term of government. The dominance of political factors in budgetary decision-making is well documented by Ohnsorge-Szabó and Romhányi (2007) who show that in the absence of politically motivated spending ${ }^{19}$ since 2000 public debt would have been 36.9 percent of the GDP in 2006 instead of the 66 percent (265).

\section{Figure 4. General government deficits: history and goals (\% of GDP)}



1. The dotted line from 2008 to 2010 shows the deficit path as outlined in the Govemment's Convergence Programme of November 2007. The figure for 2007 (5.7\% of GDP) corresponds to the government estimate of the year's cuttum as of March 2008. This figure compares with an original target of $6.8 \%$ of GDP.

Source: OCED (2008): 13

On the surface the persistence of electoral considerations after 2000 is due to two factors: the large number of elections and referenda in this period ${ }^{20}$ and the intensifying antagonism between the major political parties after the close outcome of the 2002 elections that brought back to power the Hungarian Socialist Party. However if we look deeper we can identify three factors that contribute to the dominance of election cycles in economic policy-making:

1. In line with the theoretical considerations, in a low-trust environment support can be bought only through short-term material benefits and thus regardless of the ideological leaning of the parties, overspending is the norm rather than the exception. This

\footnotetext{
${ }^{19}$ Among others these include subsidized credit for housing, increase in the public sector wage bill, increase in pensions and other social security benefits.

${ }^{20}$ These include municipal elections in the autumn of 2002, referendum on accession to the European Union in May 2003, European parliamentary elections in May 2004, referendum on dual citizenship and hospital privatization in December 2004 followed by the parliamentary elections in 2006.
} 
phenomenon also implies that the public is unaware of the consequence of irresponsible fiscal policy, and fiscal illusion ${ }^{21}$ is rampant.

2. The institutional structure provides ample opportunity for the political class to manipulate the budget according to electoral considerations ${ }^{22}$ as well as contributes to the fiscal illusion of the electorate ${ }^{23}$. Naturally policy-makers have no incentive to strengthen these institutions as that would only make vote-buying more difficult for them.

3. There is no external factor that would enforce discipline and the international financial markets provide financing to cover the imbalances ${ }^{24}$.

By 2006 the third condition began changing. The forint weakened substantially in July 2006 and there was a sharp fall of portfolio inflows (IMF 2006: 4-5). Changing investor sentiment showed that adjustment cannot be postponed further. In response to these pressures the new government implemented a front-loaded adjustment, in which the main elements were tax increases (for VAT, social security and corporate tax), administrative measures to reduce the size of the grey economy and a wage freeze in the public sector. Expenditure-cut measures were the decreasing of subsidies for transport, energy and pharmaceuticals. The government also tried to introduce structural reforms in health care and education through introducing the visit fee, daily fee for hospitals as well as tuition ${ }^{25}$.

While as it can be seen from Figure 4 fiscal balance improved due to these measures international experiences suggest that a mainly revenue-based consolidation is neither longlasting nor growth-promoting ${ }^{26}$. Two years after the consolidation the consequences confirm the experiences of other countries as economic growth slowed down considerably while there was no upturn in investment (European Commission 2008: 89). The sustainability of the package became even more questionable after the referendum in March 2008 when three symbolic elements of the package (visit fee, hospital daily fee and tuition) were rejected by an over 80 percent majority in a referendum, which also reflected the enormous dissatisfaction of the public. Following the referendum the governing coalition fell apart and the Socialists formed a minority government, which makes it highly unlikely that any kind of reform would be forthcoming.

Overall the period since 2000 manifests fully the difficulties of structural reforms in a lowtrust environment and the working of a vicious cycle. The imbalances, which are due to populist electoral politics, are eventually consolidated through sub-optimal revenue-increasing measures that lead to a worsening business environment ${ }^{27}$. The increase in taxes and the

\footnotetext{
${ }^{21}$ The concept of fiscal illusion was originally formulated by Buchanan and Wagner (1977) and it means that the public overvalues the benefits of current government spending and discounts future taxes. In Hungary this was manifested in a Gallup survey between the two rounds of parliamentary elections in 2006, which showed that only 18 percent of the voters of the winning party considered the high fiscal deficit a serious economic problem.

${ }^{22}$ The major problems of the institutional framework concern the overly optimistic planning of the budget, the lack of restrictions during the adoption phase to increase spending, the discretion of the government to change the budget during the execution phase as well as the lack of transparency. The extreme weakness of the Hungarian institutional framework for budgeting even in a Central European comparison has been noted by a number of observers. See Gleich (2003), Kraan et al (2007) or Fabrizio and Mody (2008).

${ }^{23}$ The attempts in 2004 and 2005 to hide the budget deficit through creative accounting are examples of this relation. For these measures see Kraan et al (2007): 12.

${ }^{24}$ The consequences of the lack of external pressure either from the international capital markets or the European Union is discussed by Györffy (2007).

${ }^{25}$ For a detailed overview pof the measures see Government of the Republic of Hungary (2006).

${ }^{26}$ See Alesina, Perotti and Tavares (1998) and Ardagna (2004).

${ }^{27}$ See Györffy (2008) on the relationship between political trust and choosing the method of consolidation.
} 
administrative measures to fight the grey economy substantially increase the administrative costs in the economy and create an unfavorable environment for investment ${ }^{28}$. Small and medium-size enterprises are particularly hard hit since they do not have the means to lobby individual exemptions from taxes or regulations (OECD 2008: 147). As this sector employs $69 \%$ of the labor force in Hungary, it is unsurprising that after Malta and Poland, Hungary has the third lowest employment rate in the European Union at 57,3 percent in 2007 (Eurostat). Low employment in turn affects both growth and the fiscal balance. As labor is underutilized, growth prospects of the country decline. Low employment also means low contribution to the budget while at the same time entrenches demand for high welfare provisions. These provisions then have to be financed by high taxes on those who work, which provides considerable incentives for tax evasion and little incentive to work legally. These developments undermine public trust in the state even further and thus create a vicious cycle between lack of trust and growth. Figure 5 provides a stylized summary of these relationships.

Figure 5. Vicious cycle of low trust and poor growth performance

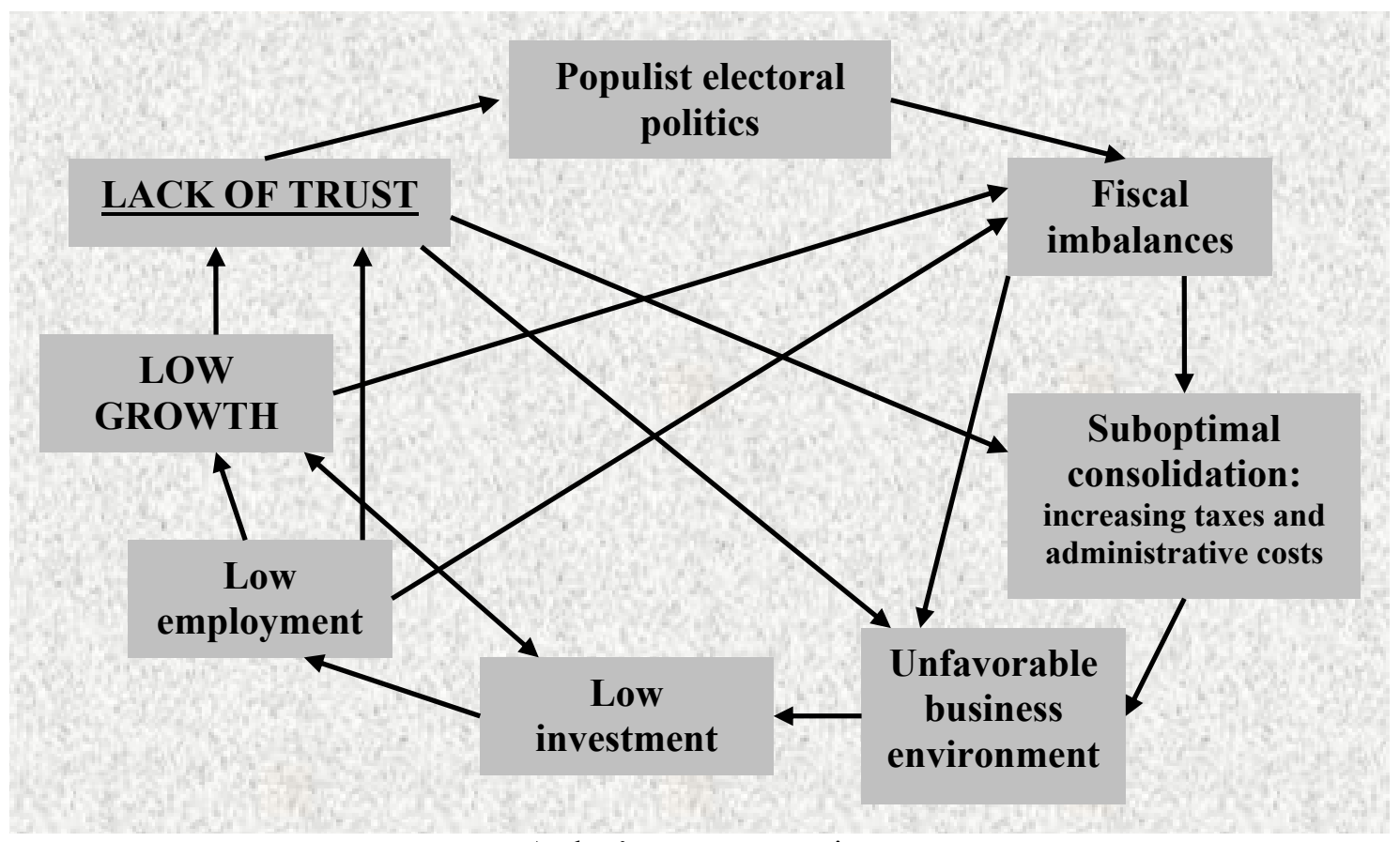

Author's own construction

As a result of the vicious cycle that emerged in Hungary since 2000 the convergence process reversed and now Hungary is diverging from the European average. This is shown by Figure 6. The figure also shows that in 2007 Slovakia surpassed Hungary. The next section examines the causes behind this development.

\footnotetext{
${ }^{28}$ The rankings of various international institutions reflect these developments. On the World Bank "ease of paying taxes" list Hungary ranks 127th out of the 178 countries just ahead of Vietnam (World Bank 2008: 4749). Hungary also has the highest tax wedge after Belgium among the OECD countries (OECD 2007: 14). Administrative costs in the economy reach 6.8 percent of the GDP, the highest in the European Union (European Commission 2006: 3). For an extensive overview of the relationship between competitiveness and administrative regulations in Hungary see Török (2007).
} 
Figure 6. Convergence in the New Member States of the EU (PPP)

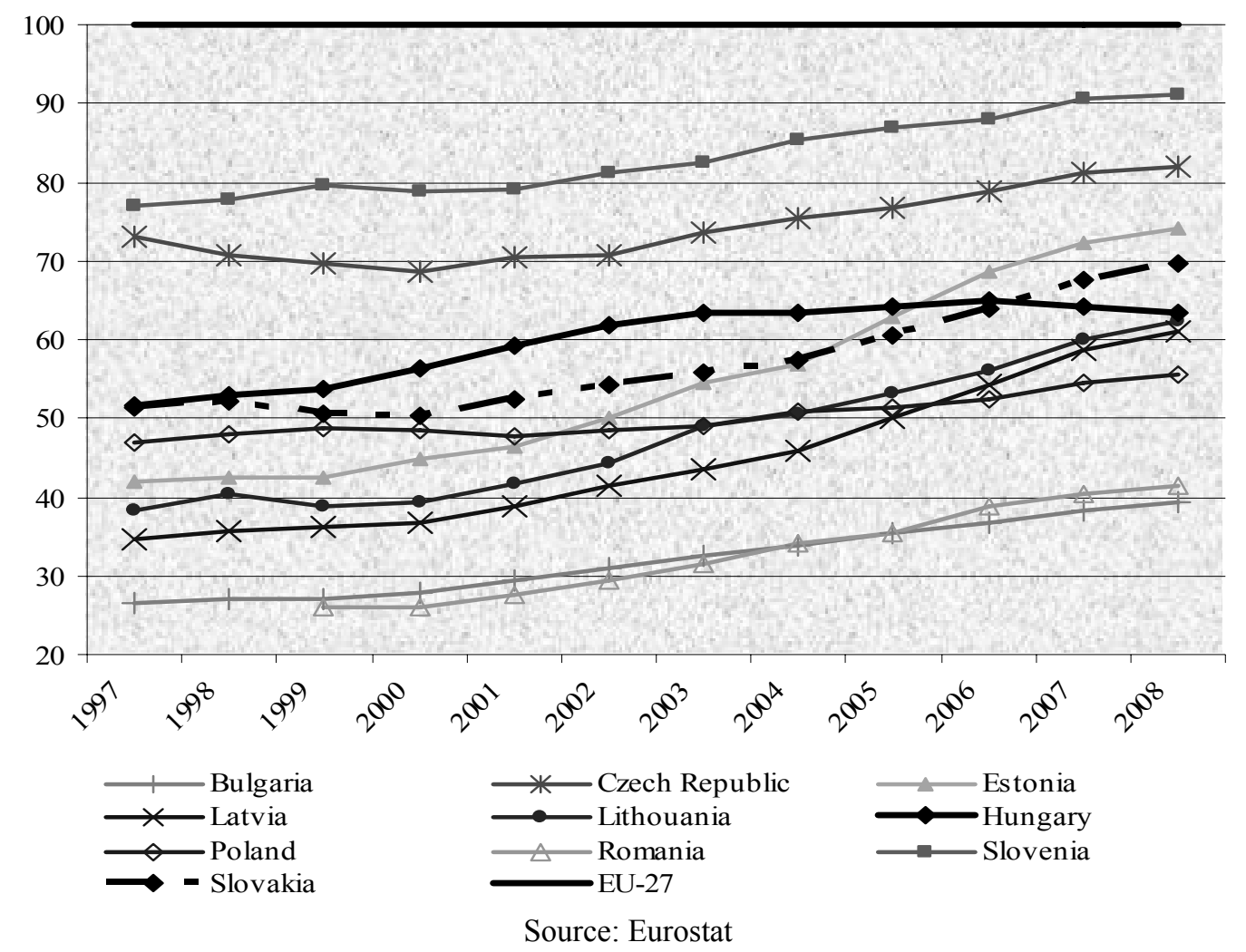

\section{From isolation to star performer: reforms in Slovakia}

\section{Postponing transformation under Meciar}

Czechoslovakia entered the transition period without any of the reforms that took place in Hungary since 1968. This made shock therapy, simultaneous stabilization and liberalization, necessary at the beginning of transition (Bokros 2007: 248), which were implemented by Vaclav Klaus in January 1991. Given its lower level of development Slovakia was particularly hard hit by these measures - between 1990 and 1992 its GDP declined by 22 percent and employment fell by 13 percent. The respective figures in the Czech Republic were 13 percent and 9 percent (UN ECE 2003: 112 and 115). This lent increasing support to the vigorous opposition of Vladimir Meciar who argued that transition polices should be tailored to Slovakia's special conditions and cause minimal social disruption (Fisher et al 2007: 987).

Looking only at the aggregate numbers it would appear that Meciar reached his goals. After a sharp initial downturn GDP started to recover already in 1994, while inflation was reduced below 10 percent by 1996 (Morvay 2000: 22). However the favorable macroeconomic indicators hid serious microeconomic problems. Unlike in Hungary privatization took place via voucher methods (1990-1992) and domestic sales (1994-1996) with the exclusion of foreign investors. The problem with the first method was that it produced diffuse ownership and in the absence of minority shareholder protection rights it provided considerable opportunities for investment fund managers to enrich themselves (Marcincin 2000a: 300-303). As they supported Meciar's opponents, from 1994 privatization proceeded through a series of direct sales mainly to political allies, the former communist managers (Fisher et al 2007: 988). Other aspects of economic policy (state aid, favorable public contracts, state guarantees on 
loans, lack of bankruptcy enforcement and creditors' right protection) complemented the political objectives of privatization and helped to preserve the inherited industrial structure (Marcincin 2000b: 331-332).

The result of the above policy was a growing fiscal deficit although hidden through creative accounting $^{29}$ as well as a steady deterioration of international competitiveness, which was manifested in the worsening current account ${ }^{30}$. The lack of international competitiveness also meant the accumulation of non-performing loans in the banking sector reaching 41 percent by 1998 (Barto 2000: 365). At the same time the soft policies that postponed restructuring were unable to protect jobs and unemployment remained steadily over 10 percent (Morvay 2000: 22).

The fall of Meciar however was not primarily due to the economy. The ensuing corruption, disregard of the constitution, criminal methods to deal with opponents, strong nationalist rhetoric and mistreatment of the Hungarian minority ${ }^{31}$ together led to international isolation. In the economy this was shown by the lack of FDI inflows thus making the country reliant on foreign loans to finance the twin deficit (Fisher et al 2007: 988). Even more critical was the fact that in contrast to the other Visegrád countries, Slovakia was refused first-wave accession into both the NATO and the European Union.

\section{Building credibility during the first Dzurinda government}

International rejection deeply hurt Slovak national pride and undermined Meciar's capacity to mobilize nationalism for his survival (Greskovits 2008: 25). In 1998 the anti-Meciar forces won the elections, which mobilized 84.4 percent of the Slovak voters. The new coalition led by Mikulas Dzurinda included the Christian Democrats (SDK), the former reformCommunists (SDL) and the Party of Ethnic Hungarians (SMK). While the presence of former communists made radical change impossible, the prospect of EU accession held the coalition together and the government succeeded in the most urgent tasks.

The most important task was to regain the confidence of the international organizations. This was done through a very strong cooperation with the European Union during which Slovakia implemented all the necessary measures without asking for exceptions or special treatment during the negotiation process (Fisher et al 2007: 990). The international community responded well to Slovakia's efforts and in 1999 the European Commission revised its previous opinion and concluded that Slovakia fulfilled the Copenhagen political criteria. The country also joined the OECD in 2000 and the NATO in 2002.

Besides building international credibility, the government introduced an austerity package to stabilize public finances, which turned out to be in a worse state than expected. In addition to severely restricting government expenditures, the package included a 7 percent import surcharge, which not only meant increased revenues but also contributed to reducing the

\footnotetext{
${ }^{29}$ Tóth (2000) provides data from the Ministry of Finance, showing that after the initial shock of the creation of the new state fiscal prudence was observed as after 1994 the budget deficit was never higher than 5 percent (6364). However he also notes the unreliability of this information and the difficulties of knowing the real balance (65). In hindsight his analysis was correct - net lending reached -8.6 percent in 1996 and -6.7 percent in 1997 (European Commission 2007: 208).

${ }^{30}$ The current account deficit remained over 9 percent between 1996 and 1998 (European Commission 2007a: 208)

${ }^{31}$ On Meciar's anti-democratic practices see Fish (1999) and Baer (2000)
} 
current account deficit (Suster 2004: 66). The government also encouraged the inflow of FDI through tax and tariff breaks as well as the privatization of banks and state monopolies. The sale of state banks after restructuring, which cost 13 percent of the GDP in 2000, resulted in a 97 percent foreign ownership of total private Slovak banking capital (Suster 2004: 69).

While the reforms were far from popular and unemployment reached its peak at 19.8 percent in 1999, the success of the Dzurinda government in regaining international confidence helped the government in narrowly winning the elections in 2002 and forming an ideologically coherent center-right coalition without the former communists.

\section{Radical reforms by the second Dzurinda government (2002-2006)}

Freed from the tasks of European accession, from 2002 the newly elected government embarked on a series of radical reforms, which aimed to address the country's desperate employment performance via neoliberal policies. The main principles driving the reforms were to increase incentives for employment, investment and job creation (Árendás et al 2006: 229). In order to reach these objectives systemic measures were implemented in public finance and the market regulatory framework. The main elements were the following ${ }^{32}$ :

- Flat tax: introduction of a uniform 19\% rate for corporate tax, personal income tax and VAT. The idea behind this measure was to tax all income equally regardless of its source, eliminate the numerous exceptions that characterized the prior system and simplify tax administration to reduce tax evasion (Árendás et al 2006: 230-232). Through providing tax bonus after every child the system also aimed to motivate employment.

- Public finance responsibility: increasing budgetary transparency, introducing program budgeting and developing a medium-term macroeconomic framework in order to improve the cost-effectiveness of tax-payers' money. As a result of the reforms Slovakia now has the fourth strongest budgetary framework in the European Union (European Commission 2007b: 125).

- Labor market reforms: in order to increase the flexibility of the labor market the power of trade unions were curbed and employment protection regulations eased (Fisher et al 2007: 982).

- Regulatory reforms: easing the process of establishing and closing a business through simplified procedures and more effective registration of property.

- Social policy reforms: aimed to end the situation when under certain conditions receiving aid was more beneficial to a family than gaining employment (Király et al 2006: 259-260). The length of unemployment insurance was reduced from 9 to 6 months, while the replacement ratio decreased from $60 \%$ of the previous wage to $50 \%$. The reform of sickness benefits meant that the first 10 days of sickness was paid by the employer, which gave incentive for better monitoring. Receiving unemployment benefits was tied to actively searching for a job.

- Pension reform: in order to deal with the consequences of aging population, the age limit for retirement was raised to 62 years and a three-pillar pension system was introduced.

\footnotetext{
${ }^{32}$ Due to space constraint and the nature of the article the following overview can only be an incomplete list of the measures rather than an exhaustive analysis. For a detailed summary and evaluation of the reforms see the edited volumes of Zachar (2004) and Zachar (2005).
} 
- Health care reform: the reform sought to transform providers into competing businesses and opened up the insurance market to private competitors. Consumers were discouraged to seek unnecessary care through the introduction of co-payment fees (Fisher et al 2007: 984).

- Judicial reform: fight corruption in the legal profession as well as implement a new set of penalties to encourage socially functional behavior (Fisher et al 2007: 985).

The above measures were widely hailed among international observers and in 2005 Slovakia was named top reformer of 2003 by the World Bank (2005). The international acclaim was supported by the strong performance of the economy that could be observed in the acceleration of growth, decreasing unemployment and declining inflation (Figure 7).

Figure 7. GDP growth, unemployment and inflation in Slovakia 2003-2009

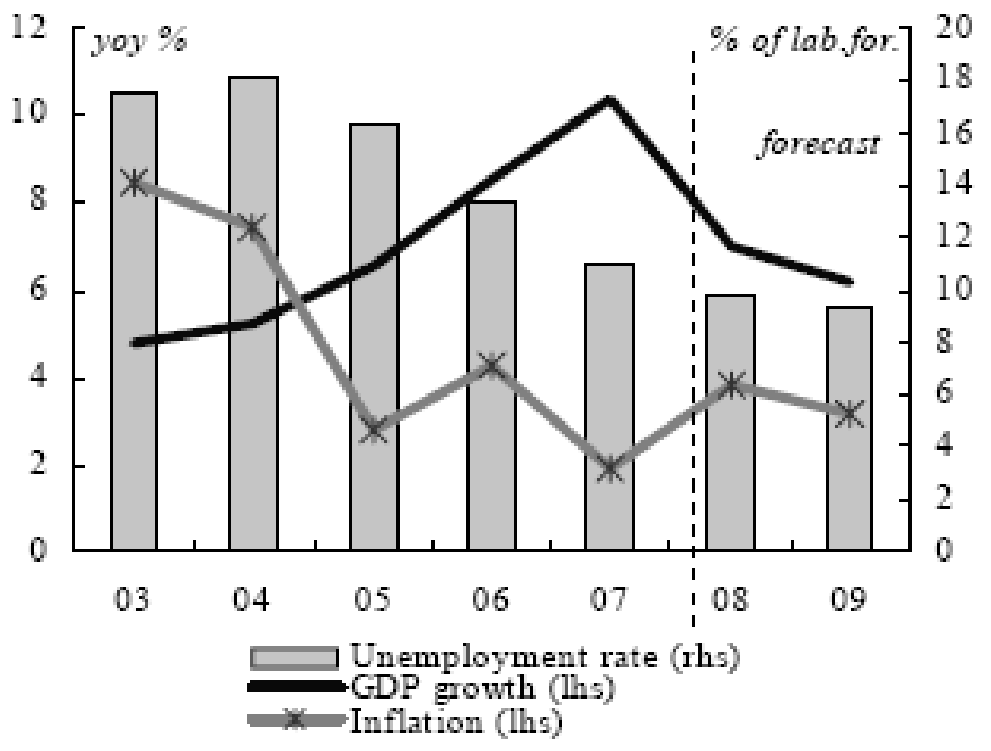

Source: European Commission (2008): 106

The reforms however were not without costs. The low-skilled, the unemployed and the pensioners were especially hard-hit as their benefits were reduced while the prices of food and utilities rose (Moore 2005: 24-27). The food riots and violent demonstrations during 2004 in mainly Roma-populated areas in Eastern Slovakia manifested the hardship of the reforms and the unequal regional distribution of benefits. The inequality is also shown by the fact that about two-thirds of the employees earn less than the average monthly wage (EIU 2006a: 14). The resulting public disaffection was shown during the 2006 elections, where an extremely low turnout (54 percent) produced a convincing majority for the left-wing anti-reform forces led by Robert Fico's SMER.

\section{Mild reversal of reforms and EMU accession (2006-2008)}

While the populist rhetoric of the new government and the return of Meciar to government provoked speculations about the fate of Dzurinda's reforms, fears of a complete reversal proved to be unfounded. The budget submitted in December 2006 reflected the maintenance of the flat tax system as well as the commitment to EMU accession (Fisher et al 2007: 995). At the same time in spite of the maintenance of the main elements of the reforms a gradual softening of policies took place. Immediately after assuming power the Fico-led government abolished the highly unpopular copayment in health care, decreased the VAT rate for 
foodstuff, increased state support of utility prices as well as ruled out privatization of 'strategic' enterprises including the Bratislava airport and the rail transport firm ZSSK Cargo (EIU 2006b: 22-23).

The slight turnaround however did not undermine the reform structure built by the previous government. This was recognized in the European Commission's assessment in May 2008 that Slovakia was ready for the euro. Furthermore the rapid growth and increasing employment made the Fico government highly popular, while Dzurinda remains one of the most unpopular public figures in Slovakia (EIU 2007: 13).

\section{Implementing reforms in a low-trust environment}

The experiences of almost two decades of transition in Hungary and Slovakia allow some general inferences regarding the conditions under which reforms become possible even in an environment where lack of trust is likely to increase resistance to reforms. In the theoretical part of this paper four possibilities were identified that allow reforms to be implemented in spite of lack of trust. As both Hungary and Slovakia are democratic states, we can exclude authoritarian measures from these four factors. In the following the remaining three possibilities are examined in the two cases: crisis, reformers' credibility and elite consensus.

Crisis played an important role in reforms both in Hungary and Slovakia. In Hungary the fear of an imminent collapse was instrumental in the implementation of the Bokros package as well as the fiscal consolidation in 2006, while in Slovakia the international isolation as a result of Meciar's policies was seen as critical. When discussing the role of crisis in reforms, Rodrik (1996) calls such explanations problematic as they are both tautological and nonfalsifiable: if the economy in crisis is not reformed, then the explanation that the crisis has not been severe enough is rather unsatisfying (27). This criticism is valid in these cases as well, and leads us to recognize that any such explanation is necessarily based on perceptions rather than objective reality. This means that it is impossible to tell the degree of deterioration that is necessary for politicians and electors to initiate change in previously followed policies. In 1995 there was no need for collapse of the Hungarian economy and the government implemented the stabilization package as a preventive measure ${ }^{33}$. In Slovakia the fear of being left out from the European Union was instrumental in generating the perception of crisis. However the management of crisis and its exploitation for structural reforms strongly depended on the reformers.

Reformers' credibility was also instrumental for the success of reforms. The commitment and determination of Bokros and Dzurinda to implement a liberal reform agenda were not questioned even by their harshest opponents. Their critics at home rather focused on the necessity of such reforms, while investors were convinced about the advantages as manifested by the accelerating investment activity after the reforms. The failure of the Gyurcsány government to implement structural reforms also underlines the importance of credibility. As

\footnotetext{
${ }^{33}$ The difference between avoiding a crisis and responding to a crisis is also emphasized by Kornai (1996). On a more general level Martinez-Moyano et al (2007) underline that the judgement and interpretation of a given situation form the basis for the government's decisions. This approach gives an important role to learning as the deviation between the predicted and actual outcome can improve future judgements in the case of repeated decision-making (5-7).
} 
Gyurcsány admitted in the infamous lie speech ${ }^{34}$ the responsibility for the near-crisis situation in 2006, his motives and ability to reform was called into serious doubt. The over 80 percent rejection of the three symbolic elements of reform at the referendum in March 2008 signaled that the public was unwilling to accept restrictions from politicians primarily responsible for the need for such measures. While investors were more favorable to the consolidation package, the lack of credibility is evident even in their case: as discussed in the previous section in spite of the measures to bring down the fiscal deficit investment activity remained stagnant, which is contradictory to the experiences of successful consolidations.

Elite consensus played an important but marginal role in reforms both in Hungary and in Slovakia. In Hungary the early consensus that characterized the transition was instrumental in hardening the budget constraint and the privatization to foreigners. With such a consensus in place there was no need for a crisis to implement the necessary policies. Lacking such consensus it took almost a decade of experimenting for Slovakia to follow this course. However the disillusionment from the transition and its exploitation by the major parties led to the collapse of the early consensus in Hungary without its recovery in sight. Consensus was even more absent in Slovakia during the nearly two decades of transition. The only important exception is the introduction of the euro to which Fico remained committed in spite of his populist discourse. However even in this case consensus did not mean discussions on policy and shared responsibility but rather was the response to pressures from business interest groups who had a stake in introducing the common currency (Fisher et al 2007: 995). In the public discourse recent Slovakian politics seems as confrontational as Hungarian politics ${ }^{35}$, which does not bode very well for the future of the reforms. These cases support the theoretical considerations about the difficulties of consensus-building in a low-trust environment.

Summing up the results of the comparison between Hungary and Slovakia the following reform dynamics appears. In the absence of an elite consensus a perception of crisis by the elite is necessary for changing the unsustainable policies. Once a window of opportunity appears for reforms, the human factor becomes critical in the quality and quantity of measures. This factor is probably the main reason for the recent success of Slovakia: unlike in Hungary, where reform-minded politicians (Kupa, Bokros) were in power for no longer than one year, the group of reformers led by Dzurinda had two full terms to implement farreaching changes. While in both cases a reversal of the measures could be observed after the fall of the reformers, the critical mass of reforms implemented by Dzurinda was more difficult to reverse than the measures of the stabilization package implemented by Bokros. However, a common factor in both cases is the lack of elite consensus, which can eventually erode the results. Table 2 summarizes the reform dynamics in the two countries.

Through examining the reform dynamics from a long-term perspective it becomes possible to speculate on the future course of economic policy in the two countries. The vicious cycle of poor performance and public dissatisfaction as well as the shock presented by Slovakia's

\footnotetext{
${ }^{34}$ After the successful elections, in May 2006 Ferenc Gyurcsány gave a speech to the Socialist party members of the newly elected Parliament at Balatonöszöd. In the speech he admitted lieing day and night about the true state of the country in order to win the elections. The speech was secretly recorded and on 17 September it was broadcasted by the Hungarian Radio. The content and obscenity of the speech ignited mass protests around Hungary and riots in Budapest in the following months.

${ }^{35}$ Reporting on the reactions to the admittance of Slovakia into the EMU, the English-language Slovakian newsportal, The Spectator, underlines Fico's lack of acknowledgment for Dzurinda's reforms in preparing the accession and his emphasis on his own measures in bringing the economy back from collapse in 2006. See: http://www.spectator.sk/articles/view/31695/11/a_great_day_for_slovakia.html
} 
admission to the EMU can open up a window of opportunity for reforms in Hungary. Once this window is open, it depends on the individual policy-makers how far reforms proceed. In contrast, Slovakia's recent success and the emergence of a populist discourse strongly point towards the slowdown of the reform process. The likelihood of this course is increased by its admission to the EMU and the subsequent loss of the external anchor for discipline ${ }^{36}$. It remains to be seen whether the Fico government has internalized the necessity for responsible policies and can find other ways to maintain its popularity.

Table 2. Summary of reform dynamics in Hungary and Slovakia

\begin{tabular}{|l|l|l|l|}
\hline Hungary - period & \multicolumn{1}{|c|}{ Hungary - policy } & Slovakia - period & \multicolumn{1}{|c|}{ Slovakia - policy } \\
\hline $1990-1991$ & $\begin{array}{l}\text { Reform measures through elite } \\
\text { consensus }\end{array}$ & $1990-1992$ & Shock therapy by Klaus \\
\hline $1992-1994$ & $\begin{array}{l}\text { Transformational recession and } \\
\text { breakdown of consensus }\end{array}$ & $\begin{array}{l}1993-1998 \\
\text { Successful shock therapy by } \\
\text { Lajos Bokros }\end{array}$ & $\begin{array}{l}\text { 'Slovak way' to transition by } \\
\text { Meciar }\end{array}$ \\
\hline $1995-2000$ & $\begin{array}{l}\text { Enjoying the results of the } \\
\text { stabilization, slow reversal of } \\
\text { reforms }\end{array}$ & $\begin{array}{l}\text { (Identity) crisis and fall of } \\
\text { Meciar } \\
\text { Overstretching possibilities, } \\
\text { emergence of a vicious cycle }\end{array}$ & $\begin{array}{l}\text { Building international and } \\
\text { domestic credibility by the first } \\
\text { Dzurinda government }\end{array}$ \\
\hline $2001-2006$ & $\begin{array}{l}\text { Moderately successful fiscal } \\
\text { consolidation but unsuccessful } \\
\text { structural reforms }\end{array}$ & $\begin{array}{l}\text { Implementing radical structural } \\
\text { reforms by the second Dzurinda } \\
\text { government }\end{array}$ \\
\hline $2008-$ & $\begin{array}{l}\text { ??Muddling through, crisis or } \\
\text { emergence of credible } \\
\text { reformers? }\end{array}$ & $\begin{array}{l}\text { Enjoying the results of the } \\
\text { reforms, slow reversal of } \\
\text { reforms }\end{array}$ \\
\hline
\end{tabular}

Author's own construction

\section{Conclusions}

The original objective of this article was to explain the strikingly different performances of Hungary and Slovakia as reflected in their compliance with the Maastricht criteria. Emphasizing the difficulties of reforms in a low-trust environment this article pointed out the cyclicality of reforms without the presence of an elite consensus. Looking at Hungary and Slovakia from such a perspective two factors can be emphasized to account for their differences: the longer rule of reformers in Slovakia and the different phase of the reform cycle.

The above conclusions point to the difficulties associated with sustainability in a low-trust regime. Even if a crisis opens the window of opportunity for reforms the strong pressures for short-term policies can eventually erode the results. This implies that for lasting changes the difficult task of consensus-building cannot be avoided. However consensus itself is conditional upon public trust - as long as there is a strong incentive towards populism from the public a political group is likely to emerge to respond to these incentives. This leads to the conclusion that building public trust in the system is a major factor in achieving sustainable development, which does not predict an easy road towards convergence either for Hungary or Slovakia.

\footnotetext{
${ }^{36}$ Once within the euro-zone the lack of a strong enforcement of the Stability and Growth Pact implies a serious moral hazard problem for the leaders. See: Győrffy (2007).
} 


\section{Bibliography}

Ábel István (2002): „Real Dangers in Banking Crises: Examples of Failed Hungarian Banks.” In: Green, David and Karl Petrick (eds.): Banking and Financial Stability in Central Europe: Integrating Transition Economies into the European Union. Cheltenham, UK: Edward Elgar. pp. 153-176.

Ábel, Isván and Szakadát László (1997): “A bankrendszer átalakulása Magyarországon 19871996 között." [The transformation of the banking system in Hungary between 1987 and 1996.] Közgazdasági Szemle. 44 (7-8): 635-552.

Alesina, Alesina, Roberto Perotti and Jose Tavares. 1998. „The Political Economy of Fiscal Adjustments" Brookings Papers on Economic Activity (1): 197-266.

Antal, László (2007): “Mi változott és mi nem? Reformhullámok és stagnáló szakaszok váltakozása Magyarországon." [What changed and what did not? Reformwaves and stagnation periods in Hungary]. In: Muraközy, László ed.: Fecseg a felszín és hallgat a mély. Tudatok és tudatalattik a gazdaságpolitikában. Budapest: Akadémiai Kiadó. pp. 48-79.

Anderson, Christopher J, Andre Blais, Shaun Bowler, Todd Donovan and Ola Listhaug (2005): Losers' Consent: Elections and Democratic Legitimacy. Oxford: Oxford University Press.

Appel, Hilary and John Gould (2000): "Identity Politics and Economic Reform: Examining Industry-State Relations in the Czech and Slovak Republics." Europe-Asia Studies. 52 (1): 111-131.

Árendás, Csaba, Tamás Dudás, Gábor Illés and Marianna Szinek Kékesy (2006): “The Tax Reforms in Slovakia in 2004 - the Year of 19\%." In: Béla Keszegh and Tamás Török eds. Gazdasági váltás Szlovákiában - Economic Reforms in Slovakia. Komárom - Komárno: Kempelen Farkas Társaság. pp. 223-256.

Ardagna, Silvia. 2004. "Fiscal Stabilizations: When Do They Work and Why." European Economic Review. 48 (5): 1047-74.

Bare, Josette (2000): “Boxing and Politics in Slovakia: 'Meciarism' - Roots, Theory, Practice." Democratization 8 (2): 97-116.

Balázs, Péter (1996): 'Integration Objectives of Hungary." European Business Journal. 8 (3): 21-28.

Barro, Robert J. and David B. Gordon (1983): "Rules, Discretion and Reputation in a Model of Monetary Policy.” Journal of Monetary Economics. 12 (1): 101-120.

Barto, Martin (2000): "Banking Sector in the Slovak Republic." In: Anton Marcincin and Miroslav Beblavy eds. Economic Policy in Slovakia 1990-1999. Bratislava, Slovakia: INEKO. pp. 358-375.

Benczes, István (2008): Trimming the Sails: The Comparative Political Economy of Expansionary Fiscal Consolidations. Budapest and New York: Central University Press. 
Blind, Peri K. (2007): "Building Trust in Government in the Twenty-First Century: Review of Literature and Emerging Issues." $7^{\text {th }}$ Global Forum on Reinventing Government: Building Trust in Government. Vienna, Austria: United Nations. Available: http://unpan1.un.org/intradoc/groups/public/documents/un/unpan025062.pdf Accessed: 12 May, 2008.

Bokros, Lajos (1993): "Hosszú menetelés a konvertibilitás felé." [Long march towards convertibility]. In: Magyarország Politikai Évkönyve 1992. Budapest: DKMK. pp. 317-318.

Bokros, Lajos (2007): “ Az állam alkati torzulásainak eredete az átmeneti társadalmakban.” [The origins of state distortions in transition societies.] In: László Muraközy ed. Fecseg a felszín és hallgat a mély. Budapest: Akadémiai Kiadó. pp. 213-257.

Bozóki András (2003): Politikai pluralizmus Magyarországon. [Political Pluralism in Hungary.] Budapest: Századvég.

Buchanan, James M. and Richard E. Wagner (1977): Democracy in Deficit: The Political Legacy of Lord Keynes. Academic Press INC.: San Diego and London.

Csaba László (1998a): “A második reformtól a rendszerváltozáson át a szociális piacgazdaságba." [From the second reform through the transition to social market economy.] In: Szamuely, László and László Csaba: Rendszerváltás a közgazdaságtanban közgazdaságtan a rendszerváltásban. [Transition in economics - economics in transition]. Budapest: Közgazdasági Szemle Alapítvány. pp. 71-185.

Csaba László (1998b): “A Decade of Transformation in Hungarian Economic Policy: Dynamics, Constraints and Prospects." Europe-Asia Studies. 50 (8): 1381-1391.

Drazen, Allan and Vittorio Grilli (1992): "The Benefit of Crises for Economic Reforms." American Economic Review. 83 (3): 598-607.

Easton, David (1965): A Systems Analysis of Political Life. New York: Wiley.

EBRD (2007): Life in Transition: A survey of people's experiences and attitudes. London: EBRD.

EIU (2006a): Country Report Slovakia August 2006. London: Economist Intelligence Unit.

EIU (2006b): Country Report Slovakia November 2006. London: Economist Intelligence Unit.

EIU (2007): Country Report Slovakia May 2007. London: Economist Intelligence Unit.

Elster, Jon (2000): Ulysses Unbound: Studies in Rationality, Precommitment and Constraints. Cambridge: Cambridge University Press.

European Commission (2006): „Measuring administrative costs and reducing administrative burdens in the European Union." Commission Working Document No. 2006(691). 
European Commission (2007a): Statistical Annex of European Economy. Brussels: Directorate General for Economic and Financial Affairs.

European Commission (2007b): Public Finances in EMU - 2007. Brussels: Directorate General for Economic and Financial Affairs.

European Commission (2008): Spring Economic Forecasts 2008-2009. European Economy No. 3. Brussels: Directorate General for Economic and Financial Affairs.

Fabrizio, Stefania and Ashoka Mody (2008): "Breaking the Impediments to Budgetary Reforms: Evidence from Europe.” IMF Working Paper No. 08/82.

Fish, Steven (1999): “The End of Meciarism." East European Constitutional Review. 8 (1-2): 47-55.

Fisher, Sharon, John Gould and Tim Haughton (2007): "Slovakia's Neoliberal Turn.” EuropeAsia Studies. 59 (6): 977-998.

Gleich, Holger (2003): "Budget Institutions and Fiscal Performance in Central and Eastern European Countries.” Working Paper No. 215. Frankfurt: European Central Bank.

Government of the Republic of Hungary (2006): "Convergence Program of Hungary." Budapest.

Greskovits, Béla (2008): "Hungary and Slovakia: Compliance and Its Discontents." Manuscript.

Győrffy, Dóra (2007): "Deficit Bias and Moral Hazard on the Road to the EMU: The Political Dimension of Fiscal Policy in Hungary.” Post-Communist Economies. 19 (1): 1-16.

Győrffy, Dóra (2008): "Political Trust and the Success of Fiscal Consolidation: Lessons from Sweden and Hungary." Zeitschrift für Staats- und Europawissenschaften. 6 (1): 75-100.

IMF (2004): "Fostering Structural Reforms in Industrial Countries." In: World Economic Outlook. April. Washington: International Monetary Fund. pp. 103-146.

IMF (2006): “Hungary - Selected Issues.” IMF Country Report No. 06/367.

Király, Zsolt, Péter Kürthy, Péter Sidó and Krisztina Száraz (2006): "Reform of the Social Security System in Slovakia." In: Béla Keszegh and Tamás Török eds. Gazdasági váltás Szlovákiában - Economic Reforms in Slovakia. Komárom - Komárno: Kempelen Farkas Társaság. pp. 257-288.

Kornai, János (1996b): “Kiigazítás recesszió nélkül.” [Stablization without recession.] Közgazdasági Szemle. 43 (7-8): 585-613.

Kornai János (2005): A gondolat erejével. [By Force of Thought.] Budapest: Osiris.

Kornai, János (2006): “The Great Transformation of Central Eastern Europe: Success and Disappointment." Economics of Transition. 14 (2): 207-244. 
Kraan, Dirk-Jan, Daniel Bergvall, Ian Hawkesworth and Philipp Krause (2007): "Budgeting in Hungary." OECD Journal on Budgeting. 6 (3): 1-61.

Kydland, Finn E. and Edward C. Prescott (1977): "Rules rather than Discretion: The Inconsistency of Optimal Plans." Journal of Political Economy. 85 (3): 473-491.

Laki, Mihály and Júlia Szalai (2006): "The Puzzle of Success: Hungarian Enterpreneurs at the Turn of the Millenium.” Europe-Asia Studies. 58 (3): 317-345.

László, Csaba (2001): "Vargabetük az államháztartási reform tízéves történetében (19881997)." [Twists and turns in the ten-year history of Hungarian public finance reforms (19881998)]. Közgazdasági Szemle. 48 (10): 844-864.

Lengyel, László (1998): Pártházból palotába. [From party headquarters to castles.] Budapest: Helikon.

Marcincin, Anton (2000a): "Privatization." In: Anton Marcincin and Miroslav Beblavy eds. Economic Policy in Slovakia 1990-1999. Bratislava, Slovakia: INEKO. pp. 292-319.

Marcincin, Anton (2000b): "Enterprise Restructuring." In: Anton Marcincin and Miroslav Beblavy eds. Economic Policy in Slovakia 1990-1999. Bratislava, Slovakia: INEKO. pp. 320357.

Martinez-Moyano, Ignacio J. et al (2007): "Investigating the Dynamics of Trust in Government: Drivers and Effects of Policy Initiatives and Government Action." Available: http://www.dis.anl.gov/publications/articles/Trust_in_Government\%202007.pdf Accessed: 12 May, 2008.

Mihályi, Péter (2001): „The Evolution of Hungary’s Approach to FDI in Post-Communist Privatization." Transnational Corporations. 10 (3): 61-74.

Mihályi Péter (2005): A privatizáció szellemi elökészitése. [The intellectual foundations of privatization.] Budapest: ÁPV Rt.

Moore, David (2005): "Slovakia's 2004 Tax and Welfare Reforms." IMF Working Paper No. $05 / 133$.

Morvay, Karol (2000): “Overall Macroeconomic Development." In: Anton Marcincin and Miroslav Beblavy eds. Economic Policy in Slovakia 1990-1999. Bratislava, Slovakia: INEKO. pp. 18-59.

O’Dwyer, Conor and Branislav Kovalik (2007): "And the Last Shall be First: Party System Institutionalization and Second-Generation Economic Reforms in Postcommunist Europe." Studies in Comparative International Development. 41 (4): 3-26.

OECD (2007): Taxing Wages 2006/2007. Paris: OECD.

OECD (2008): Reforms for Sustainable Growth: An OECD Perspective on Hungary. Paris: OECD. 
Ohnsorge-Szabó László és Romhányi Balázs (2007): "Hogy jutottunk ide: magyar költségvetés, 2000-2006." [How we got here: Hungarian fiscal policy 2000-2006.] Pénzügyi Szemle. 52 (2): 239-285.

Olson, Mancur (1965): The Logic of Collective Action. Cambridge, MA and London: Harvard University Press.

Rodrik, Dani (1996): "Understanding Economic Policy Reform.” In: Journal of Economic Literature. 34 (1): 9-41.

Rogoff, Kenneth (1985): "The Optimal Degree of Commitment to a Monetary Target." Quarterly Journal of Economics. 100 (4): 1169-1190.

Rose, Richard (2006): „Diverging Paths of Post-communist Countries : New Europe Barometer Trends since 1991." Studies in Public Policy No. 418. Glasgow: Centre for the Study of Public Policy.

Rothstein, Bo (2005): Social Traps and the Problem of Trust. Cambridge: Cambridge University Press.

Suster, Martin (2004): “Developments of Slovakia's Economy since 1990.” In: Bruno S. Sergi and William T. Bagatelas eds.: The Slovak Economy and EU Membership. Bratislava: IURA. pp. $48-85$.

Szalai Júlia (2007): Nincs két ország...? Társadalmi küzdelmek az állami (túl)elosztásért a rendszerváltás utáni Magyarországon. [No two countries? Social struggles for state (over)redistribution in post-transition Hungary.] Budapest: Osiris.

Tóth, Ján (2000): "Fiscal Policy" In: Anton Marcincin and Miroslav Beblavy eds. Economic Policy in Slovakia 1990-1999. Bratislava, Slovakia: INEKO. pp. 60-93.

Török Ádám (2007): “A versenyképesség egyes jogi és szabályozási feltételei Magyarországon." [Legal and regulatory conditions of competitiveness in Hungary.] Közgazdasági Szemle. Vol. 54. No. 12. 1066-1084.

UN ECE (2003): Economic Survey of Europe 2003 No. 2. Geneva, Switzerland: United Nations Economic Commission for Europe.

Várhegyi Éva (2002): Bankvilág Magyarországon. [The world of banks in Hungary]. Budapest: Helikon.

Voszka, Éva (1998): Spontán privatizáció. [Spontaneous privatization]. Budapest: APV Rt.

World Bank (2005): Doing Business in 2005: Removing Obstacles to Growth. Washington: World Bank.

Zachar, Dusan (2004): Reforms in Slovakia 2003-2004. Bratislava: INEKO.

Zachar, Dusan (2005): Reforms in Slovakia 2004-2005. Bratislava: INEKO. 